\title{
A review of the broodstock management and larviculture of the Pacific northern bluefin tuna in Japan
}

\author{
Shukei Masuma ${ }^{1}$, Takayuki Takebe ${ }^{2}$, Yoshitaka Sakakura ${ }^{3 *}$ \\ ${ }^{1}$ Miyazu Station, National Center for Stock Enhancement, Fisheries Research Agency, Kyoto \\ 626-0052, Japan \\ ${ }^{2}$ Yaeyama Station, Seikai National Fisheries Research Institute, Fisheries Research Agency, \\ Okinawa 907-0451, Japan \\ ${ }^{3}$ Faculty of Fisheries, Nagasaki University, Bunkyo 1-14, Nagasaki 852-8521, Japan
}

*Corresponding author. Tel./fax.: (+81) 958192823

E-mail address: sakakura@nagasaki-u.ac.jp

\begin{abstract}
We reviewed research on the broodstock management and larviculture of the Pacific northern bluefin tuna (PBT) Thunnus orientalis in Japan. Japan has been at the forefront of PBT research since 1970 due to the participation by federal and prefectural governments and universities in a national project aimed to optimize productivity of the sea around Japan. In 1979, scientists at Kinki University succeeded in the first spontaneous spawning in captivity by the broodstock of 5 year-old PBT. Successful spawning was also performed in 1980 and 1982, but no spawning then occurred until 1993, when Maruha Nichiro Holdings, Inc. (MNH) and Nippon Formula Feed Manufacturing Company, Ltd. (NFFMC) became involved in tuna farming and succeeded in the spawning of four-year-old broodstock. Since then, successful spawning of PBT in captivity has been reported from several sites as well as spawning in Kinki Univ. since 1994. With the successful spawning of PBT, the Fisheries Research Agency (FRA; formerly, Japan Sea Farming Association) of Kinki University, in conjunction with MNH, NFFMC, and Takuyo Ltd., have actively carried out research on and development of tuna larviculture technology. Thus, knowledge about broodstock management and larviculture has accumulated in Japan, but technical problems with larviculture still remain to be solved. There are 9 sites of successful spawning in net pens in Japan so far. At 4 of these sites in regions around Amami Island, yearly spawning has stably occurred. We have been accumulating data about the period of maturation, environmental key factors triggering the spawning, the age of onset of spawning, and the pattern of spawning through measurement of the ambient environment, gonad morphometry, endocrinology, mitochondrial DNA analysis, and daily careful observation of broodstock. Research on PBT larviculture at Kinki University, FRA, MNH, NFFMC, and Takuyo have succeeded in producing tens of thousands of hatchery-raised juveniles. As a result, Kinki University succeeded in establishing the full life cycle of PBT in captivity, and also achieved its aquaculture life cycle. However, solutions are needed for the remaining technological issues of PBT larviculture, including sinking syndrome, where larvae die on the bottom of the tank during the early phase of larviculture, the search for appropriate food (species, size, and nutrition) around the transition stage from larva to juvenile, cannibalism and collision against walls in the juvenile, and malformation and viral diseases in the young stage.
\end{abstract}

Keywords: Broodstock; larviculture; flow control; Thunnus orientalis 


\section{Introduction}

In the last decade, due to the high commercial value at fishery markets in Japan and rising trend in the West to consume healthy foods, there has been active farming and fattening of the bluefin tuna Thunnus orientalis (Collette, 1999) in captivity by many interested stockholders in Mediterranean countries, Mexico and Japan. However, there are some criticisms of an aquaculture system which is strongly based on wild-caught tuna, because illegal, unreported, and unregulated (IUU) PBT fishing ruin the proper management of wild stock, and lead to the extinction of PBT resources. Therefore, to sustain the tuna farming industry and preserve tuna fishery and wild tuna resources, technology for replacing wild-caught tuna with hatchery-reared juveniles needs to be developed.

Japan has led research worldwide since 1970 on the broodstock management and larviculture of Pacific bluefin tuna (PBT) due to involvement by the federal and prefectural governments and universities in a national project intended to optimize productivity of the sea around Japan (Anonymous, 1992). In 1979, Kinki University succeeded in the first spontaneous spawning by broodstock of 5 year-old bluefin tuna in captivity. After the university again achieved successful spawning in 1980 and 1982, no spawning occurred until 1993. Following this success, in 1986 Nippon Formula Feed Manufacturing Company, Ltd. (NFFMC) followed by Maruha (now called Maruha Nichiro Holdings, Inc.: MNH) in 1987 became involved in tuna farming and succeeded in the spawning of 4 year-old broodstock. Since then, the successful spawning of bluefin tuna in captivity has been reported from several sites. With the successful spawning of bluefin tuna, $R \& D$ for tuna larviculture technology has been actively carried out by Kinki University, the Japan Sea Farming Association (now called the Fisheries Research Agency (FRA)) (Masuma, 2008), MNH, NFFMC, and Takuyo Ltd. As a result, understanding of the PBT broodstock in captivity has increased. Additionally, knowledge has accumulated on the period of maturation/spawning, environmental key factors causing the spawning, the age of onset of spawning, and the pattern of spawning through such approaches as measuring the ambient environment, gonad morphometry, endocrinology, mitochondrial DNA analysis, and daily careful observation of broodstock (Hirota and Morita, 1976; Miyashita et al., 2000; Masuma et al., 2003; Seoka et al., 2007, Masuma et al., 2008; Masuma, 2008).

Research on larviculture at Kinki University, FRA, MNH, NFFMC, and Takuyo have succeeded in producing tens of thousands of hatchery-raised juveniles based on technologies developed in Japan. Kinki University has consequently succeeded in establishing the full life cycle of the Pacific bluefin Tuna in captivity, and also achieved its aquaculture life cycle (Kumai and Miyashita, 2003; Sawada et al., 2005). Nevertheless, solutions are needed for the remaining technological issues of Pacific bluefin larviculture, such as sinking death on the bottom of the tank in the early life stage, called 'sinking syndrome', the search for appropriate food (kind, size, and nutrition) for tuna larvae between the larvae and juvenile stages, cannibalism, bumping against walls, malformation, virus diseases, and other problems.

Financial support from the Japan Fisheries Agency and efforts by private companies, including those mentioned above, focusing on broodstock management and fingerling production have allowed projects that will help stabilize the tuna farming industry and consequently conserve wild tuna resources to be conducted.

\section{Broodstock management and successful spawning}

\subsection{Facilities for broodstock}

The locations of the PBT broodstock are along the coastline of Japan at the edge of the Kuroshio Current and the Tsushima warm current (Fig. 1). 
The PBT broodstock, which grow rapidly to a giant size of about $600 \mathrm{~kg}$ in body weight at the largest, are maintained in larger net pens as grow-out. Additionally, since PBT broodstock require rearing for an extended period of over 3 years (over $100 \mathrm{~kg}$ ) at the earliest from wildcaught yearling tuna until maturity to make spawning possible, larger net pens are better because they prevent the fish from bumping against net walls (Kumai, 1997; Miyashita, 2001). Anchored floating net pens consisting of nets and ropes with floats measuring 20-80 $\mathrm{m} \times 20-50$ $\mathrm{m} \times 10-15 \mathrm{~m}$ deep are popular in Japan. Floating pens are an oval shape because tuna swim in a circular pattern within the pen. Net pens with steel frames allow workers to walk safely on the frame while collecting the eggs. These pens are used at research institutes such as Kinki University and the Amami station of the Fisheries Research Agency (FRA) (Masuma et al., 2008a; Masuma, 2008b). The FRA has an extensive facility for sustaining the PBT broodstock consisting of a closed cove and two barrier nets (called a barrier-net closed cove) to hold the broodstock (Fig. 2). Its internal water area is about 14 ha. The barrier net closed cove was constructed because bluefin tuna are highly migratory, and produce more eggs when they are given sufficient space to swim, grow, mature, and spawn freely.

\subsection{Management of broodstock}

Yearling bluefin tuna are collected by commercial fisherman trolling lines with barbless hooks, and recently purse seine nets only in the Japan Sea. The caught tuna are held in sea pens and mainly fed sand lance Ammodytes personatus, horse mackerel Trachurus japonicus, and chub mackerel Scomber japonicus at the rate of 1.5-11 \% of the body weight per day as growout at FRA (Masuma et al., 1991, Masuma, 2006a).

The causes of mortality of the PBT broodstock maintained in a sea pen are injuries caused by bumping against the net wall, particularly injuries due to fatal damage to the eyes because of rapid growth, high rearing density and 'burst' swimming. Masuma et al. (2001) suggested that one of the causes for the bumping is visual disorientation due to the incompatibility of the retinal adaptation with the change in the ambient light intensity at dawn. PBT in captivity have less diseases, with the exception of an iridovirus disease which breaks out in yearling tuna kept at temperatures over $21^{\circ} \mathrm{C}$ (Sawada, 2005).

There are no reports on the appropriate density of PBT broodstock. The maximum density of tuna farming is experienced at $3 \mathrm{~kg} / \mathrm{m}^{3}$ (Sawada, 2005), and fish density at harvest is approximately $1 \mathrm{~kg} / \mathrm{m}^{3}$ on an empirical basis (Masuma et al., 2008). Therefore, PBT broodstock density should be restricted to less than $1 \mathrm{~kg} / \mathrm{m}^{3}$ to lessen the mortality.

The growth of PBT broodstock in captivity is strongly dependent on the ambient water temperature (Fig. 3). Water temperature strongly affects feeding activity and active feeding of PBT in the net pens can be observed over $20^{\circ} \mathrm{C}$ (Hirota et al., 1976; Masuma et al., 1991; Masuma et al., 2008)

\subsection{Maturation and spawning in captivity}

There have been four reports on the gonadal maturation of PBT in captivity (Miyashita et al., 2000; Masuma, 2006a; Masuma, 2006b; Seoka et al., 2007a). Seasonal changes in the gonadosomatic index (GSI) of males and females, which reflects the gonadal maturation of the fish, were reported by these researchers. The GSI of male PBT begins to elevate from April with a peak around June-July (Miyashita et al., 2000; Masuma, 2006a), and are sustained by September in Amami Island (Masuma, 2006a), although male BFTs with a high GSI value occur less after the peak. Seoka et al. (2007a) observed that the mature testes in even 2 and 3 year-olds with seminiferous lobule lumina and a main sperm duct were filled with spermatozoa in September at Amami Island, and Masuma (2006a) observed active sperm in the testes of 2 yearolds. Although not all male BFT broodstock are mature at 2 years old, precocious male BFT 
might potentially be able to reproduce in captivity. The GSI of females begins to elevate from May with a peak in July as ambient temperature rises and day length elongates (Seoka et al., 2007). Seoka et al. (2007a) reported that in 4 year old females $(130 \mathrm{~kg})$, the highest GSI $(3.0 \%)$ was in July, when spawning began. Miyashita et al. (2000a) reported the smallest female with a GSI of $4.3 \%$ was a 7 year-old (21.3 kg in body weight) who ovulated in July. It is possible that the peak of gonadal maturation of PBT is almost the same in both Amami and Wakayama, which have a difference of $5^{\circ} 19^{\prime \prime}$ in latitude. However, Masuma (2006a) reported that PBT with a GSI over $2 \%$ occurred in 6 year-olds in May and September but not in July.

The PBT broodstock maturity rate is low, as Miyashita et al. (2000a) did not find a specific peak of GSI even during the spawning period among females older than 5 years. Only one $(9.1 \%)$ of 11 female PBTs between 5 and 12 years old in captivity at the FRA station on Amami Island had a GSI over $2 \%$ in July (Masuma, unpublished data). The low maturity of the PBT broodstock in captivity is one of the important problems which need to be resolved, because a sufficient and stable amount of PBT larvae for larviculture is required for mass fingerling production to proceed.

There are 9 sites of successful PBT spawning in net pens in Japan so far, and yearly spawning has occurred stably at the Amami Island sites (Fig. 1). Recently, PBT in an aquarium at the Tokyo Sea Life Park in Japan showed spawning (Mimori et al., 2008), which indicates the possibility of PBT spawning under controlled conditions. The spawning of PBT in captivity has occurred between 3- and 12-year-old broodstock in Japan (Miyashita et al., 2000; Masuma, 2006a; Masuma et al. 2008). Although spawning at 3 years of age has succeeded at Takuyo farm since 2003, the typical start of spawning is over 5 years old (Kumai et al., 1997; Miyashita et al., 2000; Masuma, 2006a; Masuma et al., 2008), irrespective of the size of the fish. It is possible that older PBT broodstock can spawn under environmental conditions that younger PBT cannot spawn under.

The spawning of PBT broodstock (5 to 11 year-olds) in captivity in the waters of Amami occurs intermittently from mid-May to early November, with a peak during June-July (Masuma, 2006a). Miyashita et al. (2000) determined the spawning period of PBT broodstock (5 to11 year-olds) in captivity at Wakayama as between mid-June and mid-August.

The water temperature at the beginning of spawning ranged from $23.5-27.1^{\circ} \mathrm{C}$ with an average of $24^{\circ} \mathrm{C}$ (Masuma et al., 2008). Miyashita et al. (2000) suggested a relationship between ambient seasonal temperature and the spawning of PBT in captivity. Masuma et al. (2008) suggested that in years where the water temperature rises quickly from around 23 to $24^{\circ} \mathrm{C}$, spawning is more likely to occur earlier in the season, and where the water temperature rises late, spawning also occurs late, or perhaps not at all. The spawning may be influenced by rising ambient temperatures that probably result from increasing day length. It is possible that day length is also one important factor affecting sexual maturation (Bromage et al., 1990; Bromage et al., 2001) and an outbreak of spawning, as Seoka et al. (2007) reported. Further studies should be done to clarify the relationship between water temperature-day length interaction and maturation and/or spawning (Seoka et al., 2007) in order to produce eggs on a stable schedule every year in captivity.

Endocrinological studies on PBT in captivity have been conducted and are still ongoing in Japan, but the results have not yet been published. Hormonal manipulation has been actively performed on Atlantic bluefin tuna broodstock in captivity in the Mediterranean with the same aims as in Japan, and successful spawning was achieved in 2005 (Mylonas et al., 2007).

\section{Larviculture}

Mass production of Pacific bluefin tuna larvae still fluctuates due to several unresolved problems, such as initial mortality up to 10 days after hatching (60-90 \% mortality; Kumai, 1998; Miyashita, 2006), cannibalism (Sawada et al., 2005) and frequency of collision with the rearing tank after the juvenile stage (Miyashita et al., 2000). 


\subsection{Rearing in the early larval stage}

The main causes of mortality at the early phase of PBT larviculture (up to day 10) are surface tension-related death (STRD) and death at the bottom of the rearing tank by larval sinking (Miyashita, 2006), called 'sinking syndrome'. Recently, it was confirmed that the initial mortality of PBT is mainly due to sinking syndrome rather than to STRD (Tanaka et al., 2009). The sinking of PBT larvae to the tank bottom occurs at nighttime (Masuma, 2008; Tanaka et al., 2009), presumably because the larval body density of PBT is higher than that of the sea water density, and larval swimming activity is low during the night (Sakamoto et al., 2005; Takashi et al. 2006). Sinking syndrome has been reported in several fish species such as amberjack Seriola dumerili (Shiozawa et al., 2003; Teruya et al. 2009) and barfin flounder Verasper moseri (Kayaba et al., 2003). In these studies, it was found that manipulating the aeration levels to vertically mix the rearing water reduced the number of larvae sinking to the tank bottom. This may be the case in PBT larviculture, also, as water flow significantly affects the survival and feeding of PBT larvae (Kato et al., 2008).

Recently, we attempted to prevent sinking syndrome of PBT larvae by using a 'water pump system' which produces a water current at the bottom of the rearing tank at Amami Station, FRA (Tezuka et al. 2005; Masuma, 2008; Tanaka et al. 2009). The rearing tank for mass-culture in Amami Station is a long octagonal shape, $266 \mathrm{~cm}$ depth, $19 \mathrm{~m}^{2}$ in bottom area and $50 \mathrm{~m}^{3}$ in water volume (Figs. 4a, c). A water pump (CSL-100, Terada Pump Mfg Co., Ltd, Nara) was put in a rectangular net cage connected to drain $(50 \times 50 \times 150 \mathrm{~cm}, 0.252 \mathrm{~mm}$ mesh opening) at the center of the tank. Rearing sea water from the water pump was discharged via a cross-shape pipe on the tank bottom, which has $2 \mathrm{~mm}$ diameter holes at intervals of $10 \mathrm{~cm}$. The angle of water flow direction from the holes was adjusted to $45^{\circ}$ against the tank bottom. The water flow rate of the pump was adjusted to $1.0 \mathrm{~m}^{3} / \mathrm{h}$. An anti-clockwise and upward current was produced. In addition to the water pump system, two rectangular aerators $(5 \times 5 \times 17 \mathrm{~cm})$ were set next to the cage outside of drain in order to prevent larvae from aggregating into the cage mesh. The aeration rate was $1.0 \mathrm{l} / \mathrm{min}$. We conducted a 10-day rearing trial of PBT larvae using the water pump system and the former rearing method with several aerators in the rearing tank (Fig. 4b), and compared the survival of the larvae. The larvae in the water pump system showed higher survival than the larvae reared using the former method (Fig. 5), indicating that this system can significantly reduce the early mortality of PBT larvae. In this water pump system, upwelling water current is formed at the bottom of the rearing tank, and it is assumed that the upwelling current prevents the larvae from sinking. Although this system greatly improved the survival rate of larvae in some cases of mass-culture, the survival rates still fluctuated among the rearing trials. We are conducting rearing experiments with a combination of different water flows and illuminations with the aim of stable production of the early stage of PBT larviculture

\subsection{Rearing from late larval to young stage}

When PBT juveniles reach 5-7 cm in total length, they are transferred from indoor tanks to ocean net pens for grow-out using the same procedure as other marine fishes. There are two major causes of mortality in PBT larviculture from the post-flexion stage. One is cannibalism (Sawada et al., 2005) and the other is collision with the rearing tank wall and net cages (Miyashita et al., 2000).

Scombridae fishes, including PBT, show strong piscivory from the very early stage (Kaji et al., 1996; Shoji and Tanaka, 2001) compared to other piscivorous marine teleosts (Sakakura and Tsukamoto, 1996; Sakakura and Tsukamoto 2002; Sabate et al., 2009a). Cannibalism is a frequent phenomenon in PBT larviculture and sometimes the mortality caused 
by cannibalism is up to $50 \%$ during a period of several days. Aggressive behavior of PBT onsets from the post flexion stage $(6.1 \mathrm{~mm}$ in standard length) and develops thereafter, whereas schooling behavior was observed from juveniles at $23.5 \mathrm{~mm}$ (Sabate et al., 2010). Aggressive behavior in PBT is observed only under starvation, which indicates this behavior is simply related to feeding behavior, namely cannibalistic behavior (Sabate et al., 2009b). Cannibalism can be reduced by supplying sufficient amounts of appropriate diets and frequent size grading (Sawada et al., 2005).

Changes in light intensity or loud noises cause PBT juveniles to swim in panic, and collisions during high-speed swimming are often fatal (Sawada et al., 2005). Flashes of light at night, such as lightning or the lamplights of fishing boats near the PBT culture cage, sometimes lead to a high number of mortalities (Miyashita et al., 2000). Avoiding these stimuli is necessary to improve the survival of PBT juveniles. Recently, Ishibashi et al. (2009) reported that the scotopic visual threshold of juvenile PBT (about $5 \mathrm{~cm}$ in total length) was at least 40 fold inferior to the threshold of other marine teleosts, and this leads to collision with the net wall during the night and at dawn. In order to reduce the sudden changes of luminance during dawn and dusk, overhead lights providing 200-3000 lx intensity at the water surface significantly improved the survival of PBT juveniles (Ishibashi et al., 2009). However, these experiments were conducted in relatively large cage nets at the grow-out phase. Further experiments need to be performed on ways to improve the survival in indoor tanks and improve handling methods for transferring fish from indoor tanks to net cages.

\subsection{Feeding regime}

The feeding regime of PBT larviculture is basically as follows (Sawada et al., 2005): rotifers from mouth opening to $15 \mathrm{~mm}$ in total length (TL), Artemia nauplii from 6 to $30 \mathrm{~mm}$ in TL, larvae of other species such as striped beakfish Oplegnathus fasciatus or spangled emperor Lethrinus nebulosus from 10 to $40 \mathrm{~mm}$ TL and minced sand eel Ammodytes personatus from 15 $\mathrm{mm}$ TL. Fish larvae are important as a food source following rotifer/Artemia and before feeding of minced fish meat (Miyashita, 2002), because the nutrients in Artemia obstruct the growth of PBT larvae (Seoka et al., 2007b; 2008a; 2008b) and PBT cannot consume microdiets at the early juvenile stage (Takii et al., 2007). Chilean fish meal is a candidate for microdiets (Takii et al., 2007), but the development of microdiets for PBT weaning has not yet begun.

\subsection{Disease}

The mortality of yolk-sac larvae has been known to occur at some hatcheries due to infection by a protozoan endoparasite (Yuasa et al., 2007). Since this parasite infects fertilized eggs via rearing water (Yuasa et al., 2007), it can be prevented by keeping the fertilized eggs in a flow-through chamber. There are two major viral diseases in PBT. VNN occurs and causes serious damage at the early phase of PBT larviculture. Treatment of fertilized eggs with ozonated seawater and disinfection of rearing water by ozone is effective for VNN prevention (Tezuka et al., 2003). Another viral disease is by red sea bream iridovirus (RSIV), which causes high mortality at the grow-out phase (Munday et al., 2003). There is no available treatment for RSIV at present, but the Japanese project team run by FRA, Osaka University and Kinki University is developing a vaccine against RSIV.

\section{Future perspective}

It was suggested that the environmental factors related to the successful spawning of PBT in Japan would be the change and range of ambient temperature over time. From the results so far, appropriate sites for the spawning of PBT appear to be around the Amami island 
waters due to the occurrence of favorable changes and ranges of water temperature over time for maturation and stimulating the start of spawning. On the other hand, older PBT in captivity are easier to spawn than younger fish. This view suggests the necessity for extending the rearing period of broodstock in order to produce eggs on a stable schedule every year in captivity. Therefore, an important factor for the successful spawning of PBT is a location where proper management in an environment favorable for spawning is possible, one which provides good rearing conditions and food. However, at present, egg collection from PBT in Japan is still unstable because PBT spawning is easily affected by water temperature and because the broodstock maturity rate in captivity is low. Further studies need to be conducted in order to develop technology for broodstock management in ground tanks in which the water temperature and photoperiod (Mimori et al., 2008) can be controlled, although such technology will be costly. In addition, hormonal treatment to handle a large quantity of broodstock, like that developed by Mylonas et al (2007), needs to be improved.

Early survival of PBT larviculture has greatly progressed. However, problems preventing the efficient and stable production of this species still remain. A major problem is that the post-flexion larvae and early juveniles of PBT still require huge quantities of live fish larvae as diet, which is unstable, costly, laborious, and risky for viral infection and for cannibalism caused by starvation. Development of microdiets and alternative live feeds for PBT is urgently needed for their stable production. Another issue is handling and collisions at the juvenile stage, which prevent development to the grow-out phase. Further study is needed to reduce the mortality of juveniles at the grow-out phase by manipulating the proportion in the rearing tanks, keeping PBT with uniformed schools in rearing tanks and net cages, and raising fish quality in terms of tolerance to handling and other stressors.

\section{Acknowledgements}

This study was financially supported by the Research Project for Utilizing Advanced Technologies in Agriculture, Forestry and Fisheries (1905), Ministry of Agriculture, Forestry and Fisheries, Japan. We are grateful to two anonymous reviewers for their constructive comments on the earlier version of this manuscript.

\section{References}

Anonymous, 1992. Research on aquaculture and marine ranching project. In: Agriculture, Forestry and Fisheries Research Council (Eds.), Mariculture - Marine ranching projects. Kouseishakouseikaku, Tokyo, pp. 2-59.

Bromage, N., Duston, J., Randall, C., Brook, A., Thrush, M., Carrillo, M., Zanuy, S., 1990. Photoperiod control of teleost reproduction. Prog. Comp. Endocrinol. 342, 620-626.

Bromage, N., Porter, M., Randall, C., 2001. The environmental regulation of maturation in farmed finfish with special reference to the role of photoperiod and melatonin. Aquaculture 197, 63-98.

Collette, BB., 1999. Mackerels, molecules, and morphology. Soc. Fr. Ichthyol. 25, 149-164.

Hirota, H., Ikuta, Y., Morita, S., 1976. On bluefin in captivity. Saibaigiken 5, 1-9 (in Japanese).

Hirota H., Morita, M., 1976. An instance of the maturation of 3 full year old bluefin tuna cultured in a floating net. Nippon Suisan Gakkaishi 42, 939.

Ishibashi, Y., Honryo, T., Saida, K., Hagiwara, A., Miyashita, S., Sawada, Y., Okada, T., Kurata, M., 2009. Artificial lighting prevents high night-time mortality of juvenile Pacific bluefin tuna, Thunnus orientalis, caused by poor scotopic vision. Aquaculture 293, 157-163.

Kaji, T., Tanaka, M., Takahashi, Y., Oka, M., Ishibashi, N., 1996. Preliminary observations on development of Pacific bluefin tuna Thunnus thynnus (Scombridae) larval reared in the laboratory, with special reference to the digestive system. Mar. Freshwater Res. 47, 261-269. 
Kato, Y., Takebe, T., Masuma, S., Kitagawa, T., Kimura, S., 2008. Turbulence effect on survival and feeding of Pacific bluefin tuna Thunnus orientalis larvae, on the basis of a rearing experiment. Fish. Sci. 74, 48-53.

Kawamura, G., Masuna, S., Tezuka, N., Koiso, M., Jinbo, T., Namba, K., 2003. Morphogenesis of sense organs in the bluefin tuna Thunnus orientalis, The Big Fish Bang proceedings of the 26th Annual fish larval fish conference, pp 123-135.

Kayaba, T., Sugimoto, T., Matsuda, T., 2003. Mass mortality associated with sudden sinking of larval barfin flounder, Verasper moseri. Suisanzoushoku 51, 443-450.

Kumai, H., 1997. Present state of bluefin tuna aquaculture in Japan. Suisanzoshoku 45, 293-297.

Kumai, H., Miyashita S., 2003. Life cycle of the Pacific bluefin tuna is completed under reared condition. Nippon Suisan Gakkaishi 69, 124-127 (in Japanese with English title).

Masuma, S., Oka, M., Kanematu, M., Tezuka N., Teruya K., Fushimi H., Ishibashi N., 1991. Feeding and growth of captive bluefin in Yaeyama. Saibaigiken 20, 35-40 (in Japanese).

Masuma, S., Kawamura, G., Tezuka, N., Koiso, M., Namba, K., 2001. Retinomotor responses of juvenile bluefin tuna Thunnus thynnus. Fisheries Science 37, 228-231.

Masuma, S., Tezuka, N., Obana, H., Suzuki, N., Nohara, K., Chow, N., 2003. Spawning ecology of captive bluefin tuna (Thunnus thynnus orientalis) inferred by mitochondrial DNA analysis. Bull. Fish. Res. Agen. 6, 9-14 (in Japanese with English abstract).

Masuma, S., Tezuka, N., Koiso, M., Jinbo, T., Takebe, T., Yamazaki, H., Obana, H., Ide, K., Nikaido, H., Imaizumi, H., 2006. Effects of water temperature on bluefin tuna spawning biology in captivity. Bull. Fish. Res. Agen., Supplement 4, 157-172 (in Japanese with English abstract).

Masuma, S., 2006a. Studies on broodstock management and spawning ecology of bluefin and yellowfin tuna in captivity. Ph. D Thesis, Kyushu University, Fukuoka, Japan, 197pp. (in Japanese with English summary).

Masuma, S., 2006b. Maturation and spawning of bluefin tuna in captivity. Proceedings of the Kinki University International Symposium on Ecology and Aquaculture of Bluefin Tuna, 1011 November, Amami Oshima, Japan, 15-19.

Masuma, S., Miyashita, S., Yamamoto, H., Kumai, H., 2008. Status of bluefin tuna farming, broodstock management, breeding and fingerling production in Japan. Rev. Fish. Sci. 16, 411-416.

Masuma, S., 2008. Development of techniques of stock enhancement for Pacific bluefin tuna Thunnus orientalis by the Fisheries Research Agency (formerly, Japan Sea Farming Association). Journal of Fisheries Technology 1, 21-36. (in Japanese with English abstract)

Mimori, R., Tada, S., Arai, H., 2008. Overview of husbandry and spawning of Bluefin tuna in the aquarium at Tokyo Sea Life Park. Proceedings of 7th International Aquarium Congress, Shanghai, China, 130-136.

Miyashita, S., Murata, O., Sawada, Y., Okada, O., Kubo, T., Ishitani, Y., Seoka, M., Kumai, H., 2000a. Maturation and spawning of cultured bluefin tuna, Thunnus thynnus. Suisanzoshoku 48, 475-488 (in Japanese with English abstract).

Miyashita, S., Sawada, Y., Hattori, N., Nakatsukasa, H., Okada, T., Murata, O., Kumai, H., 2000b. Mortality of northern bluefin tuna Thunnus thynnus due to trauma caused by collision during growout culture. J. World Aquacult. Soc. 31, 632-639.

Miyashita, S., Sawada, Y., Okada, T., Murata, O., Kumai, H., 2001. Morphological development and growth of laboratory-reared larval and juvenile Thunnus thynnus (Pisces: Scombridae). Fish. Bull. 99, 601-616.

Miyashita, S., 2002. Studies on the seedlings production of the Pacific bluefin tuna, Thunnus thynnus orientalis. Bulletin of the Fisheries Laboratory of Kinki University 8, 1-171 (in Japanese).

Miyashita, S., 2006. Surfacing and bottoming death in seedling production. Nippon Suisan Gakkaishi 72, 947-948. 
Munday, B.L., Sawada, Y., Cribb, T., Hayward, C.J., 2003. Diseases of tunas, Thunnus spp. J. Fish Dis. 26, 187-206.

Mylonas, C., Bridges, C. Gordin, H., Belmonte Rios, A., Garcia, A., De la Gndara, F. Fauvel, C., Suquet, M., Medina, A., Papadaki, M, Heinisch, G., De Metrio, G., Gorriero, A., VassalloAgius, R., Guzman, J.M., Mananos, E., Zohar, Y., 2007. Preparation and administration of gonadotropin-releasing hormone agonist (GnRHa) implants for the artificial control of reproductive maturation in captive-reared Atlantic bluefin tuna (Thunnus thynnus). Rev. Fish. Sci. 15, 183-210.

Nakagawa, Y., Eguchi, M., Miyashita, S., 2007. Pacific bluefin tuna, Thunnus orientalis, larvae utilize energy and nutrients of microbial loop. Aquaculture 267, 83-93.

Sabate, F. de la S., Sakakura, Y., Tanaka, Y., Kumon, K., Nikaido, H., Eba, T., Nishi, A., Shiozawa, S., Hagiwara, A. , Masuma, S., 2010. Onset and development of cannibalistic and schooling behavior in the early life stages of Pacific bluefin tuna Thunnus orientalis. Aquaculture 301, 16-21.

Sabate, F. de la S., Sakakura, Y., Shiozaki, M., Hagiwara, A., 2009a. Onset and development of aggressive behavior in the early life stages of the seven-band grouper Epinephelus septemfasciatus. Aquaculture 290, 97-103.

Sabate, F. de la S., Sakakura, Y., Takebe, T., Nikaido, H., Matsumoto, N., Shiozawa, S., Hagiwara, A., Masuma, S., 2009b. Preliminary observations on the development of aggressive behavior in Pacific bluefin tuna Thunnus orientalis. Aquaculture Science 57, 329335.

Sakakura, Y., Tsukamoto, K., 1996. Onset and development of cannibalistic behavior in early life stages of yellowtail. J.Fish Biol. 48, 16-29.

Sakakura, Y., Tsukamoto, K., 2002. Onset and development of aggressive behavior in the early life stage of Japanese flounder. Fisheries Science 68, 854-861.

Sakamoto, W., Okamoto, K., Uehabu, T., Kato, K., Murata, O., 2005. Specific gravity change of bluefin tuna larvae. Nippon Suisan Gakkaishi 71, 80-82.

Sawada, Y., Miyashita, S., Aoyama, M., Kurata, M., Mukai, Y., Okada, T., Murata, O., Kumai, H., 2000. Rotifer-size selectivity and optimal feeding density of bluefin tuna, Thunnus thynnus, larvae. Suisanzoushoku 48, 169-177 (in Japanese).

Sawada, Y., 2005. Bluefin tuna. In: Kumai, H. (Eds.), Marine fish. Kouseishakouseikaku, Tokyo, pp. 173-204

Sawada, Y., Okada, T., Miyashita, S., Murata, O., Kumai, H. 2005. Completion of the Pacific bluefin tuna Thunnus orientalis (Temminck et Schlegel) life cycle. Aqua. Res. 36, 413-421.

Seoka, M., Kato, K., Kubo, T., Murai, Y., Sakamoto, W., Kumai, H., Murata, O., 2007a. Gonadal maturation of the Pacific bluefin tuna Thunnus orientalis in captivity. Aquac. Sci. $55,289-292$.

Seoka, M., Kurata, M., Kumai, H., 2007b. Effect of docosahexaenoic acid enrichment in Artemia on growth of Pacific bluefin tuna Thunnus orientalis larvae. Aquaculture 270, 193199.

Seoka, M., Kurata, M., Tamagawa, R., Biswas, A.K., Biswas, B.K., Yong, A.S.K., Kim, Y.S., Ji, S.C., Takii, K., Kumal, H., 2008. Dietary supplementation of salmon roe phospholipid enhances the growth and survival of Pacific bluefin tuna Thunnus orientalis larvae and juveniles. Aquaculture 275, 225-234.

Shiozawa, S., Takeuchi, H., Hirokawa, J., 2003. Improved seed production techniques for the amberjack, Seriola dumerili. Saibai Giken 31, 11-18. (in Japanese)

Shoji, J., Tanaka, M., 2001 Strong piscivory of Japanese Spanish mackerel larvae from their first feeding. J. Fish Biol.59, 1862-1865.

Takashi, T., Kohno, H., Sakamoto, W., Miyashita, S., Murata, O., Sawada, Y., 2006. Diel and ontogenetic body density change in Pacific bluefin tuna, Thunnus orientalis (Temminck and Schlegel), larvae. Aquac. Res. 37, 1172-1179. 
Takii, K., Seoka, M., Izumi, M., Hosokawa, H., Shimeno, S., Ukawa, M., Kohbara, J., 2007. Apparent digestibility coefficient and energy partition of juvenile Pacific bluefin tuna, Thunnus orientalis and chub mackerel, Scomber japonicus. Aquaculture Science 55, 571-577.

Tanaka, Y., Kumon, K., Nishi, A., Eba, T., Nikaido, H., Shiozawa, S., 2009. Status of the sinking of hatchery-reared larval Pacific bluefin tuna on the bottom of the mass culture tank with different aeration design. Aquacult. Sci. 57, 587-593..

Teruya, K., Hamsaki, K., Hashimoto, H., Katayama, T., Hitrata, Y., Tsuruoka, K., Hayashi, T., Mushiake, K., 2009. Ontogenetic changes of body density and vertical distribution in rearing tanks in greater amberjack Seriola dumerili larvae. Nippon Suisan Gakkaishi 75, 54-63.

Tezuka, N., Masuma, S., Takebe, T., Nikaido, H., Ide, K., 2003. Effectiveness of ozonated water for the prevention of VNN in the larviculture of Pacific bluefin tuna Thunnus orientalis. Saibai Gyogyou Center Gihou 1, 76-79 (in Japanese).

Tezuka, N., Shoma, S., Koiso, M., Takebe, T., Nikaido, H., Ide, K., 2005. Effects of light intensity and water current on the survival of the early life stages of Pacific bluefin tuna Thunnus orientalis. Saibai Gyogyou Center Gihou 3, 41-44 (in Japanese).

Yuasa, K., Kamaishi, T., Mori, K., Hutapea J.H., Permana, G.N., Nakazawa, A., 2007. Infection by a protozoan endoparasite of the genus Ichthyodinium in embryos and yolk-sac larvae of yellowfin tuna Thunnus alacares. Fish Pathology 42, 59-66. 


\section{Figure captions}

Fig. 1. Location of Pacific bluefin tuna spawning sites and farms in Japan. Closed dots denote spawning site, and open dots, farms, respectively.

Fig. 2. The barrier-net closed cove for PBT broodstock at Amami Station, NCSE, FRA, Japan.

Fig. 3. Relationship between mean water temperature and mean body weight gained at about 2.5 years old at farming sites in Japan (redrawn from Masuma et al. 2008).

Fig. 4. Schematic drawings of settings in the rearing tank for mass-culture of Pacific bluefin tuna in Amami Station, NCSE, FRA, Japan. (a) Horizontal and (b) lateral view of the water pump system, and (c) previous settings with aerators.

Fig. 5. Survival curve of Pacific bluefin tuna larvae at different water flow system.

Fig.1 Masuma etal. (2010)

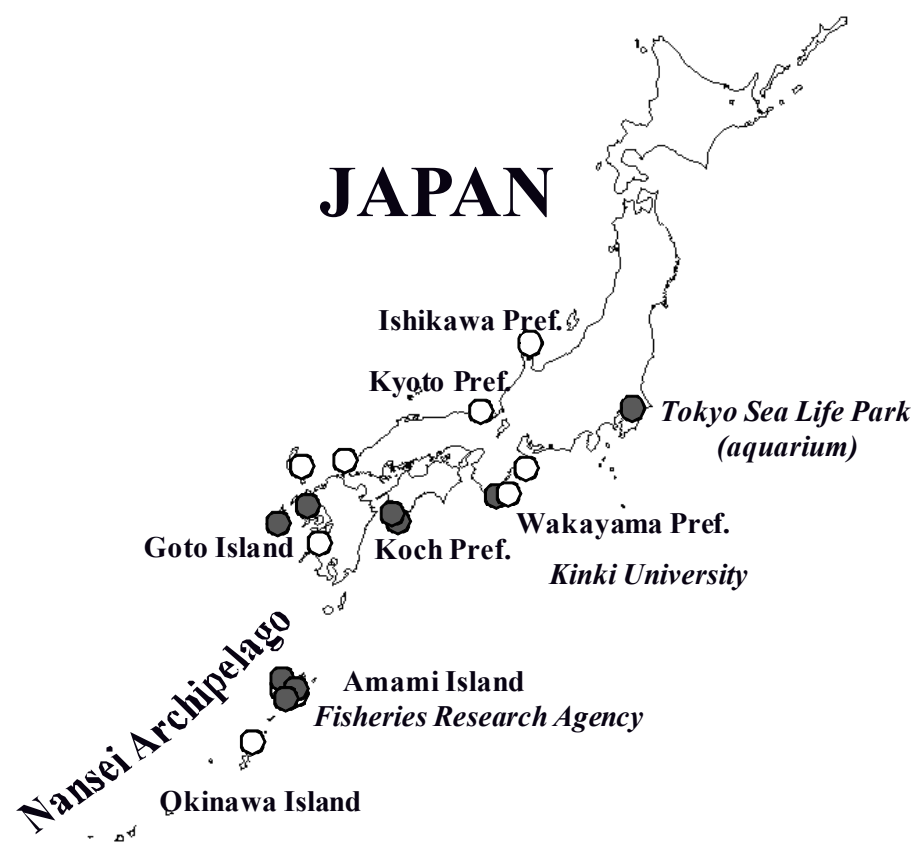


Fig.2 Masuma et al. (2010)

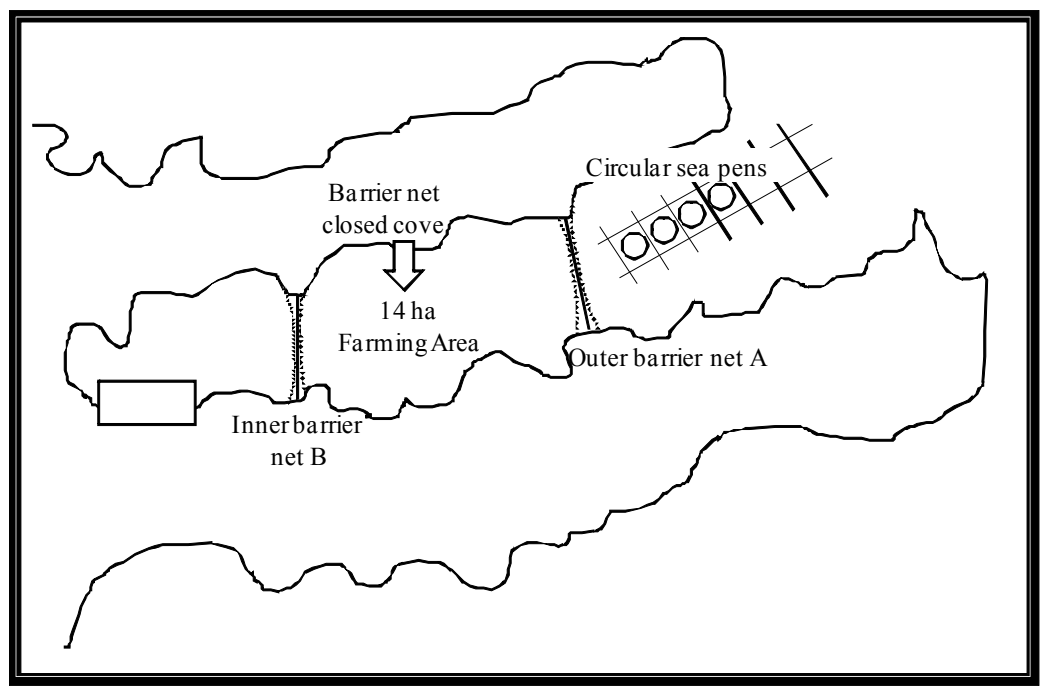

Fig.3 Masuma etal. (2010)

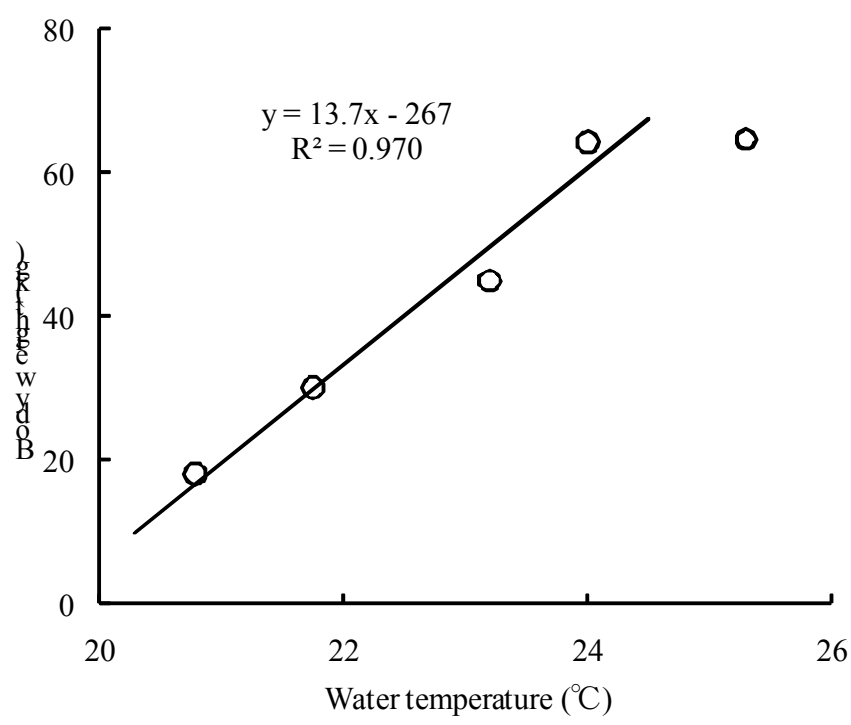



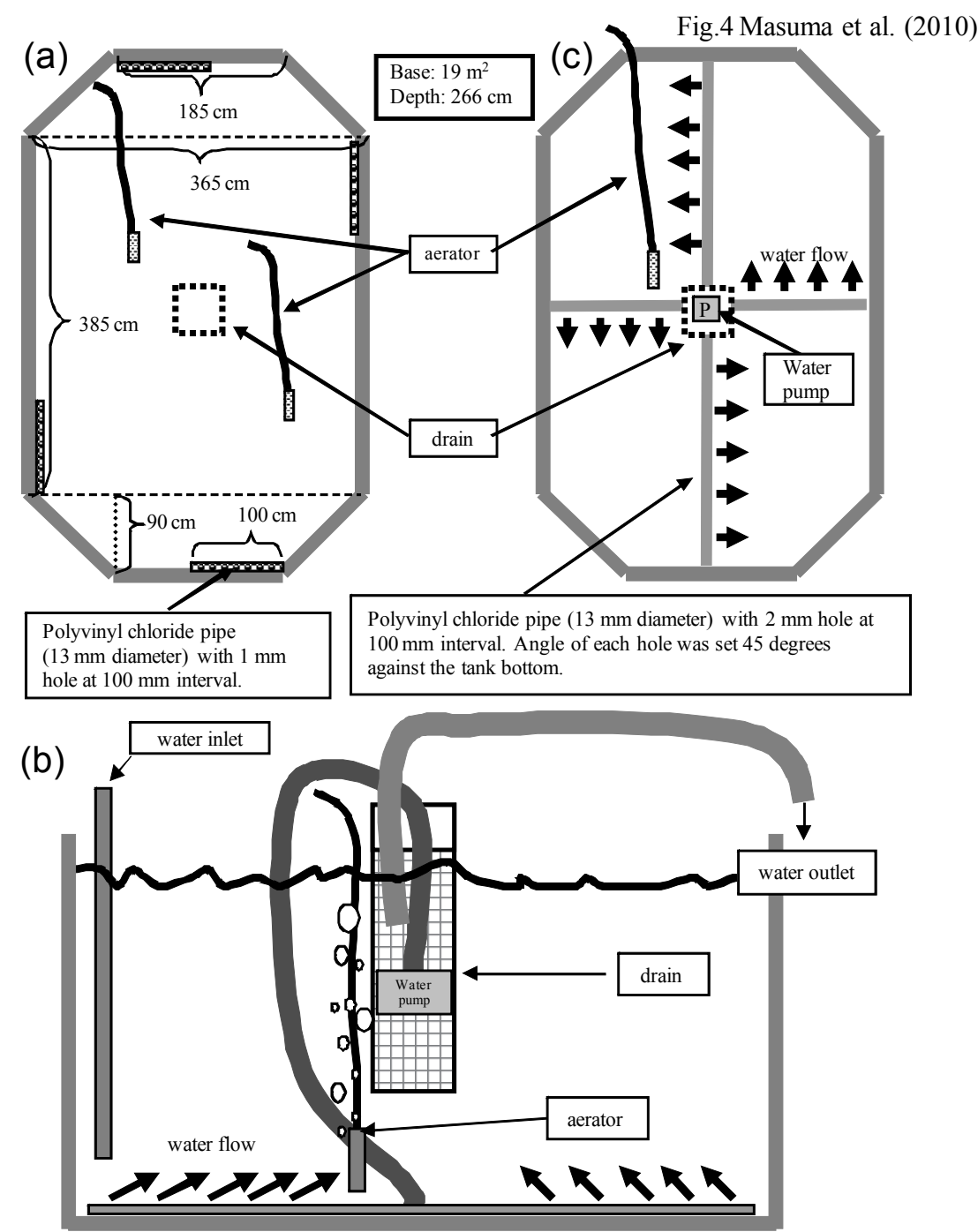

Fig.5 Masuma et al. (2010)

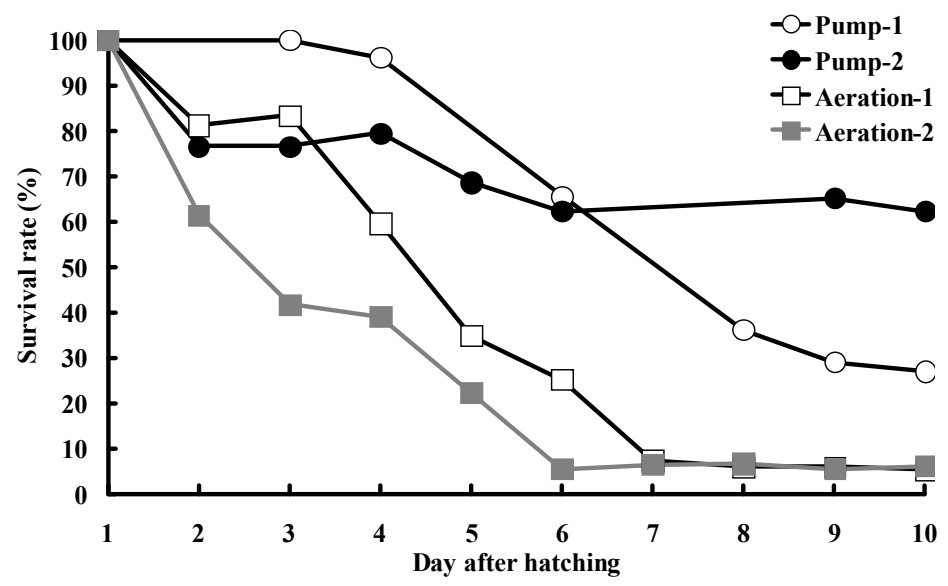

